\title{
EFFECT OF SOME BIOSTIMULANTS ON GROWTH, YIELD AND VOLATILE OIL CONTENT OF PIMPINELLA ANISUM L.
}

\author{
Ragia M. Mazrou \\ Horticulture Department, Faculty of Agriculture, Menoufia University, \\ Shibin El-Kom, Egypt
}

Received: Sep. 17, 2019

Accepted: Sep. 30,2019

\begin{abstract}
This experiment was carried out to investigate the effects of liquorice, chitosan and active dry yeast as biostimulants on the growth, fruit and volatile oil production of anise. Plants were foliar sprayed with liquorice at $20 \mathrm{~g} / \mathrm{L}$, chitosan at 400 $\mathrm{mg} / \mathrm{L}$ and active dry yeast at $6 \mathrm{~g} / \mathrm{L}$. Untreated plants were sprayed with tap water. The results revealed that foliar spraying with liquorice, chitosan or dry yeast significantly enhanced the growth characters of anise compared to the control in both the experimental seasons. Additionally, the fruit yield attributes were also considerably improved due to any biostimulant relative to untreated plants. Application of liquorice, chitosan or dry yeast not only enhanced the volatile oil yield but also increased the main components in volatile oil. Besides, photosynthetic pigments, total carbohydrates and $\mathrm{N}$, $P, K$ percentages were considerably increased due to the biostimulants treatments. Generally, the most effective biostimulant was chitosan followed by active dry yeast in two experimental seasons. To stimulate the growth and increase the quantity and quality of fruits and volatile oil yield of anise, plants should be foliar sprayed with either chitosan at $400 \mathrm{mg} / \mathrm{L}$ or active dry yeast at $6 \mathrm{~g} / \mathrm{L}$.
\end{abstract}

Key words: Lecorice; chitosan; Yeast, Volatile oil; Chlorophyll; Carbohydrates

\section{INTRODUCTION}

Anise (Pimpinella anisum L.), belongs to Apiaceae Family, is an important spice and medicinal plant. Anise is native to Mediterranean region and cultivated worldwide for fruit production which contain 2-3\% volatile oil (Hassan and Ali, 2013). Anise fruits are considered outstanding natural material for cosmetic, pharmaceutics, perfumery and food industries (Ross, 2001). Additionally, anise has gained more attention due to antioxidtaive, antimicrobial and antifungal effects on human (Tepe et al., 2006). One of the main factors affecting the productivity of anise is fertilization. Bhuvaneshwari et al. (2002) found that chemical fertilizers enhance the growth and fruit productivity of anise. However, excessive use of chemical fertilizers deteriorates soil fertility, creates pollution of agro- ecosystem and increases the production cost.

Recently, the interest of many researchers worldwide is how to produce chemical-free products to guarantee the safety and quality. To optimize the level of applied chemical fertilizers and therefore decrease the pollution some strategies have been developed including usage of untraditional fertilizers and biostimulants (Hassan and Ali, 2013; Ali and Hassan, 2014; Ali et al., 2018). Biostimulants are various substances or microorganisms used to improve the growth and development of plants and there is growing scientific evidence which supports its use as agricultural inputs on seveal plant species (Calvo et al., 2014). Liquorice root extract, obtained from Glycyrrhiza glabra, contains minerals, flavonoids, phenolic compounds, amino acids, vitamins and 
mevalonic acid which involved in gibberellins synthesis and therefore is considered a plant growth promoter (Moses et al., 2002). Foliar application with liquorice water extract not only improved the growth, fruit yield and essential oil content in coriander but also enhanced the oil composition (Abd ElAzim et al., 2017). The growth and yield of roselle were considerably improved due to liquorice treatment. Moreover, the total phenolic compounds and scavenging activity were also increased (Hassan and Abd El-Samee, 2015). The impact of liquorice root extract on growth, yield and composition has been reported in several crops (Nasser et al., 2014 on Trigonella foenum-graecum; Thanaa et al., 2016 on Prunus amygdalus).

Chitosan is a biopolymer, a chitin derivative, a natural antitranspirant, low toxic and inexpensive compound which is environmentally friendly and biodegradable with several uses in agriculture (Malekpoor et al., 2016). Chitosan stimulates vital plant processes from single cells and tissues, through physiological and biochemical processes (Hadwiger, 2013). Chitosan has proved to be operative for plant growth stimulation (Farouk et al., 2011; Karimi et al., 2012). Zhao et al. (2005) reported that chitosan is the most commonly used elicitor for enhancing the accumulation of secondary metabolites in herbs and medicinal plants since it activates genes that motivate the biosynthetic pathways of secondary metabolites (Lei et al., 2011). It has been reported that chitosan treatment improved the dry matter and volatile oil productivity in basil (Bistgani et al., 2017).

Active dry yeast is considered a plant growth enhancer as a natural cytokinins source that simulates cell division and enlargement as well as the synthesis of protein, nucleic acid and vitamin $B$ (Amer, 2004). It also releases $\mathrm{CO}_{2}$ which resulted in enhancing net photosynthesis (Kurtzman and Fell, 2005). Furthermore, Khedr and Farid (2000) found that the promotin effect of dry yeast is ascribed to its ability in stimulation of endogenous hormones such as $\mathrm{GA}_{3}$ and IAA. Yeast extract is among the most commonly elicitors which used for improving the plant growth and productivity as well as secondary metabolites accumulation (Kassem, 2013; Bistgani et al., 2017). The positive effects of dry yeast on growth and volatile oil content in several medicinal and aromatic plants were observed (El-Sayed et al., 2002 on coriander; Heikal, 2005 on thyme; SharafEldin et al., 2008 on lemon balm; Ezz ElDin and Hendawy, 2010 on Borago officinalis). Enhancing the quantity and quality of anise was and still the main goal of several researchers worldwide. However, little information is available concerning the effects of liquorice, chitosan and yeast biostimulants on the growth and productivity of anise. Therefore, the aim of this experiment was to investigate the response of anise plants to those three biostimulants and how can they affect the growth, yield and volatile oil content of anise.

\section{MATERIALS AND METHODS}

1. Plant materials and soil analysis

Two field experiments were conducted at Faculty of Agriculture, Menoufia University, Shibin El-Kom (30 $33^{\prime} 24.8^{\prime \prime} \mathrm{N}$ $31^{\circ} 00^{\prime} 51.3^{\prime \prime E}$ ) during 2017/ 2018 and $2018 / 2019$ seasons. The objective of this study was to investigate the effects of liquorice, chitosan and dry yeast on the growth, fruit yield and volatile oil content of anise plants. Seeds were obtained from Medicinal and Aromatic plants Department, Horticulture Research Institute, Ministry of Agriculture, Egypt. The experimental soil was prepared and divided to $1.8 \times 1.8 \mathrm{~m}$ plots that contained three rows with 6 hills each. The seeds were sown on October $1^{\text {st }}$ in both 
seasons. The plants were thinned after three weeks at one plant per hill. The physical properties of the used soil were ( $14.29 \%$ sand, $40.13 \%$ silt, $45.58 \%$ clay). The chemical properties of soil were $(\mathrm{pH}$, 7.98, OM, $0.17 \%$, EC, $1.30 \mathrm{dsm}^{-1}, \mathrm{SO}_{4}^{-2}$, 44.49 (meqL $\left.{ }^{-1}\right), \mathrm{Na}^{+}, 2.17\left(\mathrm{meqL}^{-1}\right), \mathrm{Ca}^{+2}$, 42.11 (meqL $\left.{ }^{-1}\right), \mathrm{HCO}_{3}, 2.03\left(\mathrm{meqL}^{-1}\right), \mathrm{Cl}^{-}$, $0.48\left(\mathrm{meqL}^{-1}\right)$, total $\mathrm{N}^{+}, \mathrm{PO}_{4}^{-3}, \mathrm{~K}^{+}$were 0.18 , 0.032 and $0.036 \%$, respectively). When required, the other cultural practices needed during the growth were done.

\section{Biostimulants treatments and experimental design}

The dried roots of liquorice were ground in a grinder and passed through a 40 mesh screen. Dried powdered sample $(20 \mathrm{~g} / \mathrm{L})$ was extracted with distilled water as recommended by Hassan and Abd ElSamee (2015). The solution was then placed in orbital shaker for $24 \mathrm{~h}$ at room temperature. Finally, the extract was filtered using Whatman filter paper No.1 and kept for spraying. Chitosan was applied at $400 \mathrm{mg} / \mathrm{L}$ as recommended by Malekpoor et al. (2016). Chitosan was initially dissolved in acetic acid (5\%) and then diluted in distilled water to the required concentration. Furthermore, active dry yeast was purchased from a local market in a powder form. Dry yeast was applied at $6 \mathrm{~g} / \mathrm{L}$ as recommended by Sharaf-Eldin et al. (2008). Aqueous dry yeast solution was overnight activated before foliar spraying application. The plants were monthly sprayed with the previous biostimulants for three times and the first one was after one month from thinning. Control plants were sprayed with tap water. The experimental design was a randomized complete design (RCD) with three replicates according to Snedecor and Cochran (1980).

\section{Growth and fruit yield characters}

At harvest stage (when fruits were greenish yellow in color and before fully ripening stage) at the April $10^{\text {th }}$ in both experimental seasons, the plants were harvested. The growth attributes i.e. plant height $(\mathrm{cm})$, branch number (main branches), herb fresh and dry weight/plant (g) were recorded. The fruit yield components i.e. number of umbels/plant, fruit yield/plant $(\mathrm{g})$ and per fed $(\mathrm{kg})$ were assessed.

\section{Volatile oil determination}

Anise fruits were dried until the weight of the sample remained constant. Dry fruit samples $(50 \mathrm{~g})$ were used for determination of the volatile oil percentage. The fruits were milled before distillation. Hydro-distillation was used for volatile oil extraction in a Clevenger apparatus for $3 \mathrm{~h}$. The distillation was done in triplicate samples and the given oil contents are the average values. The oil percentage was determined as described in British Pharmacopea (1963), using the following equation:

Volatile oil percentage $=$ oil volume in the graduated tube/weight of sample x 100 .

The oil yield (plant \& fed) was then calculated. Anhydrous sodium sulfate was used for volatile oil drying then the oil was stored in dark and cool conditions till GC-MS analysis. Samples of essential oil were performed using a Hewlett-Packard 5890 A. The oil components were identified by comparing the mass spectrum and retention times with those of standards, NIST library of the GC-MS system and literature data.

\section{Photosynthetic pigments}

The photosynthetic pigments in anise leaves were spectrophotometrically assessed according to Metzner et al. (1965) method. Fresh leaf samples were randomly collected from the middle part of stem at flowering stage for chlorophyll and carotenoids determination. The values were recorded as $\mathrm{mg} / \mathrm{g}$ based on fresh weight. 
6. Assessment of total carbohydrates

Total carbohydrate percentage was analyzed in anise leaves. Samples were dried in an oven at $70{ }^{\circ} \mathrm{C}$ for $24 \mathrm{~h}$ according to A.O.A.C. (1980). The obtained fine powder was used to evaluate total carbohydrate percentage as described by Herbert et al. (1971).

\section{Leaf mineral concentration}

Anise herb samples were oven dried at $70{ }^{\circ} \mathrm{C}$ for $\mathbf{4 8}$ hours. Samples were then milled to obtain suitable material for nutrient analysis. Samples $(0.5 \mathrm{~g})$ were digested in sulphuric and perchloric acids (Piper, 1967; Jackson, 1978) for mineral content analysis. Nitrogen was determined by the micro-Kjeldhl method according to Black et al. (1965), phosphorus were colorimetrically assessed at $660 \mathrm{~nm}$ as described by Jackson (1978), while potassium measurement was performed by flame photometer (Jackson, 1978).

\section{Statistical analysis}

The obtained data were subjected to statistical analysis using Michigan Statistical Program Version C (MSTATC). The analysis of variance (ANOVA) was performed to compare means. Means were separated using Duncan multiple range test at 0.05 level.

\section{RESULTS AND DISCUSSION}

\section{Vegetative growth parameters}

It is evident from data presentedin Table (1) that the vegetative growth characters (plant height, branch number, fresh and dry weights) of anise were significantly enhanced due to applying the different biostimulants compared to the control in both experimental seasons. Spraying with chitosan significantly more improved the growth compared to either liquorice or dry yeast applications and recorded the highest values in this respect in both seasons. The improvement in anise growth due to liquorice extract application could be explained through its content of triterpene saponins, mevalonic acid which concert to gibberellins in plants, vitamins, polysaccharide and several minerals which play important roles in plant growth motivation (Zadeh et al., 2013; Elrys and Merwad, 2017). These results are in harmony with the results of Hassan and Abd El-Samee (2015) on roselle and Abd El-Azim et al., (2017) on fennel.

Plant growth stimulation of chitosan may be attributed to increasing the availability and uptake of water and essential elements through adjusting cell osmotic pressure and increasing antioxidants (Guan et al., 2009). It was found that chitosan increased the activities of key enzymes of nitrogen metabolism and improved the transportation of nitrogen in leaves which improved plant growth and development (Gornik et al., 2008). The current results are in agreement with the results of Malekpoor et al. (2016) on basil and Bistgani et al. (2017) on thyme. Bitelli et al. (2001) reported that chitosan treatment maintained dry matter production partly through a reduction in transpiration by induction of stomatal closure. The improvement in growth characters in the current study due to dry yeast treatment is in accordance with the results of Sharaf-Eldin et al. (2008) on lemon balm and Kassem (2013) on rosemary. Additionally, Amer (2004) reported that yeast is a source of cytokinins which simulate cell division and enlargement as well as the synthesis of protein. Such improvement was documented on several medicinal and aromatic plants (El-Sayed et al., 2002 on coriander; Heikal, 2005 on thyme; Ezz ElDin and Hendawy, 2010 on Borago Officinalis). 
Table 1. Effects of some biostimulants on vegetative growth characters of anise plant during 2017/2018 and 2018/2019 seasons.

\begin{tabular}{|lcccc|}
\hline Biostimulants & $\begin{array}{c}\text { Plant } \\
\text { height } \\
(\mathrm{cm})\end{array}$ & $\begin{array}{c}\text { Branch } \\
\text { number/plant }\end{array}$ & $\begin{array}{c}\text { Herb fresh } \\
\text { weight } \\
(\mathrm{g})\end{array}$ & $\begin{array}{c}\text { Herb dry } \\
\text { weight } \\
(\mathrm{g})\end{array}$ \\
\hline & \multicolumn{4}{c}{$2017 / 2018$ season } \\
\hline Control (Tap water) & $41.37 \mathrm{~d}$ & $4.72 \mathrm{~d}$ & $50.85 \mathrm{~d}$ & $12.37 \mathrm{~d}$ \\
Liquorice $(20 \mathrm{~g} / \mathrm{L})$ & $50.24 \mathrm{c}$ & $6.15 \mathrm{c}$ & $71.94 \mathrm{c}$ & $15.33 \mathrm{c}$ \\
Chitosan $(400 \mathrm{mg} / \mathrm{L})$ & $55.66 \mathrm{a}$ & $8.27 \mathrm{a}$ & $78.18 \mathrm{a}$ & $18.35 \mathrm{a}$ \\
Dry yeast $(6 \mathrm{~g} / \mathrm{L})$ & $52.15 \mathrm{~b}$ & $7.33 \mathrm{~b}$ & $73.76 \mathrm{~b}$ & $16.72 \mathrm{~b}$ \\
\hline & & $2018 / 2019$ season & \\
\hline Control $(T a p \mathrm{water})$ & $42.25 \mathrm{~d}$ & $4.63 \mathrm{~d}$ & $52.15 \mathrm{~d}$ & $12.45 \mathrm{~d}$ \\
Liquorice $(20 \mathrm{~g} / \mathrm{L})$ & $51.36 \mathrm{c}$ & $6.22 \mathrm{c}$ & $72.84 \mathrm{c}$ & $15.51 \mathrm{c}$ \\
Chitosan $(400 \mathrm{mg} / \mathrm{L})$ & $55.87 \mathrm{a}$ & $8.47 \mathrm{a}$ & $79.23 \mathrm{a}$ & $18.49 \mathrm{a}$ \\
Dry yeast $(6 \mathrm{~g} / \mathrm{L})$ & $53.29 \mathrm{~b}$ & $7.39 \mathrm{~b}$ & $74.88 \mathrm{~b}$ & $16.92 \mathrm{~b}$ \\
\hline
\end{tabular}

Means had different letters in each season are significantly differ from each other according to Duncan's multiple range test at $5 \%(P \leq 0.05)$.

\section{Fruit yield}

Data presented in Table (2) show that the fruit yield/plant and fruit yield/ fed were considerably enhanced as a result of applying liquorice, chitosan or dry yeast treatments relative to the control in the two experimental seasons. Moreover, plants sprayed with chitosan resulted in the highest yield compared to those sprayed with liquorice or dry yeast treatments. The fruit yield/fed was increased by 134.20 and $145.65 \%$ over control when chitosan treatment was applied in both seasons, respectively. The enhanced anise fruit yield due to liquorice application may be attributed to the improved mobilization of growthlinked metabolites dissolved substances such as mineral nutrients, soluble sugars, antioxidants, and amino acids in liquorice that positively reflect on growth enhancing and consequently fruit production. Similar trend was previously reported (Desoky et al., 2019). These results are in agreement with those obtained by Abd El-Azim et al. (2017) who found that liquorice water extract not only improved the growth but also the fruit yield of coriander. Increasing the yield due to chitosan application may be ascribed to the effective role of chitosan in improving the growth and consequently reflected in increasing the fruit yield. Similar findings were reported by Malekpoor et al. (2016). Furthermore, chitosan was found to enhance the secondary metabolites accumulation in herbs and medicinal plants (Zhao et al., 2005) through activating the genes that motivate the biosynthetic pathways of secondary metabolites (Lei et al., 2011). The current results are in agreement to those obtained by Bistgani et al. (2017) in basil. Stimulating the growth by dry yeast may be a logic reason to improve the fruit yield as well which in accordance with the results of Kassem (2013). Such increase in yield due to dry yeast treatment was documented by several researchers (El-Sayed et al., 2002 and Ezz El-Din and Hendawy, 2010). 
Table 2. Effects of some biostimulants on fruit yield and volatile oil content of anise plant during 2017/2018 and 2018/2019 seasons.

\begin{tabular}{|c|c|c|c|c|c|}
\hline Biostimulants & $\begin{array}{c}\text { Fruit } \\
\text { yield/plant } \\
\text { (g) }\end{array}$ & $\begin{array}{c}\text { Fruit } \\
\text { yield/fed } \\
(\mathrm{kg})\end{array}$ & $\begin{array}{c}\text { Volatile } \\
\text { oil (\%) }\end{array}$ & $\begin{array}{c}\text { Volatile oil } \\
\text { yield/plant } \\
\qquad(\mathrm{mL})\end{array}$ & $\begin{array}{l}\text { Volatile oil } \\
\text { yield/fed } \\
\text { (L) }\end{array}$ \\
\hline & \multicolumn{5}{|c|}{$2017 / 2018$ season } \\
\hline Control (Tap water) & $6.52 d$ & $144.89 d$ & $2.15 d$ & $0.140 d$ & $3.12 d$ \\
\hline Liquorice (20 g/L) & $11.33 \mathrm{c}$ & $251.78 c$ & $2.39 c$ & $0.271 \mathrm{c}$ & $6.02 \mathrm{c}$ \\
\hline Chitosan $(400 \mathrm{mg} / \mathrm{L})$ & $15.27 a$ & 339.33a & $2.76 \mathrm{~b}$ & $0.421 a$ & $9.37 a$ \\
\hline \multirow[t]{2}{*}{ Dry yeast (6 g/L) } & $13.87 b$ & $308.22 b$ & $2.64 a$ & $0.366 \mathrm{~b}$ & $8.14 b$ \\
\hline & \multicolumn{5}{|c|}{$2018 / 2019$ season } \\
\hline Control (Tap water) & $6.44 d$ & $143.11 d$ & 2.13d & $0.137 d$ & $3.05 d$ \\
\hline Liquorice (20 g/L) & $10.72 \mathrm{c}$ & $238.22 c$ & $2.31 \mathrm{c}$ & $0.248 \mathrm{c}$ & $5.50 \mathrm{c}$ \\
\hline Chitosan $(400 \mathrm{mg} / \mathrm{L})$ & $15.82 a$ & $351.55 a$ & $2.67 a$ & $0.422 a$ & $9.39 a$ \\
\hline Dry yeast (6 g/L) & $14.64 b$ & $325.33 b$ & $2.61 \mathrm{~b}$ & $0.382 b$ & $8.49 b$ \\
\hline
\end{tabular}

Means had different letters in each season are significantly differ from each other according to Duncan's multiple range test at $5 \%(P \leq 0.05)$.

\section{Volatile oil content and composition}

The volatile oil percentage in anise fruits and volatile oil yield were significantly increased by the various biostimulants application. Plants sprayed with liquorice, chitosan or active dry yeast recorded significantly higher fruit as well as volatile oil yield compared to the control during the two experimental seasons (Table 2). The highest volatile oil percentage and yield were obtained by applying chitosan treatment. Chitosan application was superior to liquorice or active dry yeast treatments in this respect as increased by 200.65 and $207.93 \%$ over the control in both seasons, respectively. The GC MS analysis of volatile oil was presented in Table (3). Nine components were defined in anise volatile oil and these components were $\alpha$-pinene, $\beta$-pinene, Dipentene, limonene, linalool, methyl chavicol, anethole, anis-aldehyde and carvone. The main constituents of volatile oil were anethole, carvone, anis- aldehyde and methyl chavicol. The anethole component recorded the highest percentage in volatile oil. Interestingly, liquorice, chitosan or active dry yeast applications improved the volatile oil components relative to untreated plants. Plants sprayed with dry yeast resulted in the highest percentage of anethole however, chitosan application gave the highest percentages of carvone, anis-aldehyde and methyl chavicol.

Enhancing the volatile oil content due to liquorice application may be due to its role in motivating the photosynthesis and elevating the sink capacity fulfilled during supply of photo-assimilates from leaves and consequently improved the secondary metabolites accumulation (Thomas and Howarth, 2000). Elevating the volatile oil content as a result of chitosan treatment may be due to that chitosan may act as a potent inducer for enhancing the biosynthesis of secondary metabolites. Previous reports also indicated that chitosan increased the 
essential oil content (Yin et al., 2011, on oregano and Bistgani et al., 2017 on thyme). Furthermore, accumulating more volatile oil due to dry yeast application which is in agreement with current results was previously reported by Sharaf-Eldin et al. (2008) on lemon balm; Ezz El-Din and Hendawy (2010) on Borago officinalis.

\section{Photosynthetic pigments, carbohydrate content and nutrient elements}

The results of chemical analysis of anise herb are presented in Table (4). It could be noticed that the total chlorophyll and carotenoids contents were enhanced as a result of applying the various biostimulants compared to the control in both seasons of the study. Additionally, the total carbohydrates as well as $\mathrm{N}, \mathrm{P}$ and $\mathrm{K}$ percentages were also increased due to spraying with the investigated biostimulants relative to untreated plants. The highest total chlorophyll and carotenoids contents were observed by applying chitosan treatment followed by dry yeast application without significant differences in between. Otherwise, plants sprayed with chitosan recorded the highest total carbohydrates as well as $\mathbf{N}$, $P$ and $K$ percentages in both the experimental seasons relative to either liquorice or dry yeast treated plants. The lowest values of all chemical traits investigated were recorded in control plants in both seasons. Increasing the mineral nutrients could be ascribed to the presence of these elements in liquorice extract and they are important for plant growth and development and consequently the uptake of these elements may increase as noticed in our results. In this respect, Thanaa et al. (2016) reported that liquorice extract application may increase the endogenous hormones like $\mathrm{GA}_{3}$ in treated plants which improve the metabolic processes and hence increase the nutrient content in tissues. Increasing photosynthetic pigments and carbohydrates in the current study are in accordance with the results of Nasser et al. (2014) and Hassan and Abd El-Samee (2015).

Table 3. Effects of some biostimulants on volatile oil constituents of anise fruits during $2017 / 2018$ and $2018 / 2019$ seasons.

\begin{tabular}{|c|c|c|c|c|c|c|c|c|c|}
\hline \multirow[b]{2}{*}{ Biostimulants } & \multicolumn{9}{|c|}{ Volatile oil constituents (\%) } \\
\hline & 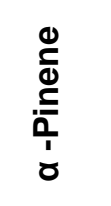 & 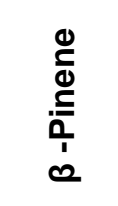 & 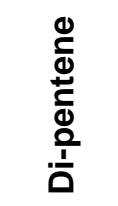 & 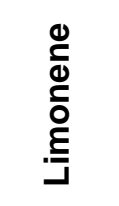 & 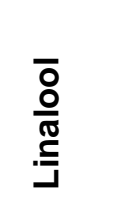 & 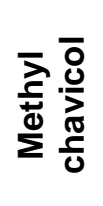 & $\begin{array}{l}\frac{0}{0} \\
\frac{5}{0} \\
\frac{0}{\alpha}\end{array}$ & $\frac{\stackrel{0}{0}}{\frac{d}{c}}$ & $\begin{array}{l}\stackrel{0}{0} \\
\stackrel{0}{\pi} \\
0\end{array}$ \\
\hline $\begin{array}{l}\text { Control } \\
\text { (Tap water) }\end{array}$ & 0.157 & 0.172 & 0.213 & 0.377 & 0.613 & 2.11 & 65.64 & 2.18 & 3.37 \\
\hline $\begin{array}{l}\text { Liquorice } \\
\text { (20 g/L) }\end{array}$ & 0.159 & 0.170 & 0.220 & 0.381 & 0.611 & 2.17 & 68.37 & 2.29 & 3.92 \\
\hline $\begin{array}{l}\text { Chitosan } \\
\text { (400 mg/L) }\end{array}$ & 0.166 & 0.181 & 0.225 & 0.379 & 0.624 & 2.33 & 73.55 & 2.67 & 5.12 \\
\hline $\begin{array}{l}\text { Dry yeast } \\
(6 \mathrm{~g} / \mathrm{L})\end{array}$ & 0.169 & 0.183 & 0.228 & 0.384 & 0.628 & 2.30 & 73.92 & 2.37 & 5.17 \\
\hline
\end{tabular}

The GC-MS was investigated in the second season of the experiment. 
It was reported that mineral nutrients maintain photosynthetic machinery through activation of the PSII reaction centers and regeneration of ribulose-1,5bisphosphate which maximize photosynthesis and elevating the sink capacity fulfilled during supply of photoassimilates from leaves (Thomas and Howarth, 2000). Therefore, the photosynthetic pigments and total carbohydrates were increased. Such increment in investigated chemical analysis due to liquorice extract was observed by Desoky et al. (2019). Our results showed that the increase of chlorophyll content by the various investigated biostimulants reflected on enhancing growth and yield attributes that might be ascribed to more assimilations correlated with nutrient elements and $\mathrm{GA}_{3}$ (Alireza et al., 2014). Improving the photosynthetic pigments due to chitosan treatment supports the findings of El-Tantawy (2009) who reported chitosan application increased photosynthetic pigments thereby increasing the photosynthesis. Otherwise, Khedr and Farid (2000) reported that dry yeast show ability in stimulation of endogenous hormones such as $\mathrm{GA}_{3}$ and IAA may increase the photosunthetic pigments and carbohydrates as well as motivating the nutrients uptake.

Table 4. Effects of some biostimulants on photosynthetic pigments, total carbohydrates and nutrient elements of anise plant during 2017/2018 and 2018/2019 seasons.

\begin{tabular}{|c|c|c|c|c|c|c|}
\hline Biostimulants* & $\begin{array}{c}\text { Total } \\
\text { chlorophyll } \\
\text { (mg/g FW) }\end{array}$ & $\begin{array}{l}\text { Carotenoids } \\
\text { (mg/g FW) }\end{array}$ & $\begin{array}{l}\text { Carbohyd- } \\
\text { rates } \\
(\%)\end{array}$ & $\begin{array}{l}\mathbf{N} \\
(\%)\end{array}$ & $\begin{array}{c}\mathbf{P} \\
(\%)\end{array}$ & $\begin{array}{l}\text { K } \\
\text { (\%) }\end{array}$ \\
\hline & \multicolumn{6}{|c|}{$2017 / 2018$ season } \\
\hline Control (Tap water) & $0.89 c$ & $0.27 c$ & $8.89 d$ & $1.22 d$ & $0.22 d$ & $1.77 d$ \\
\hline Liquorice (20 g/L) & $1.18 b$ & $0.33 b$ & $11.67 \mathrm{c}$ & $1.78 c$ & $0.29 c$ & $2.11 \mathrm{c}$ \\
\hline Chitosan $(400 \mathrm{mg} / \mathrm{L})$ & $1.32 \mathrm{a}$ & $0.42 a$ & $14.24 a$ & $2.12 a$ & $0.31 a$ & $2.43 a$ \\
\hline \multirow[t]{2}{*}{ Dry yeast $(6 \mathrm{~g} / \mathrm{L})$} & $1.31 a$ & $0.41 a$ & $12.58 b$ & $2.04 b$ & $0.29 b$ & $2.35 b$ \\
\hline & \multicolumn{6}{|c|}{$2018 / 2019$ season } \\
\hline Control (Tap water) & $0.91 \mathrm{c}$ & $0.28 c$ & $8.92 d$ & $1.25 d$ & $0.23 d$ & $1.74 d$ \\
\hline Liquorice (20 g/L) & $1.15 b$ & $0.34 b$ & $11.78 \mathrm{c}$ & $1.77 \mathrm{c}$ & $0.28 c$ & $2.31 \mathrm{c}$ \\
\hline Chitosan (400 mg/L) & $1.30 \mathrm{a}$ & $0.45 a$ & $14.77 a$ & $2.34 a$ & $0.33 a$ & $2.53 a$ \\
\hline Dry yeast (6 g/L) & $1.29 a$ & $0.44 a$ & $12.86 \mathrm{~b}$ & $2.11 b$ & $0.32 b$ & $2.44 b$ \\
\hline
\end{tabular}

Means had different letters in each season are significantly differ from each other according to Duncan's multiple range test at $5 \%(P \leq 0.05)$. 


\section{Conclusion}

Foliar spraying with liquorice, chitosan or dry yeast significantly enhanced the growth character and fruit yield components of anise. Application of those biostimulants not only enhanced the volatile oil yield but also increased the main components in volatile oil. Moreover, photosynthetic pigments, total carbohydrates and $\mathrm{N}, \mathrm{P}, \mathrm{K}$ percentages were considerably increased as well. To stimulate the growth and increase the quantity and quality of fruit and volatile oil yield of anise, foliar spraying with chitosan at $400 \mathrm{mg} / \mathrm{L}$ followed by active dry yeast at $6 \mathrm{~g} / \mathrm{L}$ was suggested. The spraying is suggested to be three times at one month interval after one month from thinning.

\section{REFERENCES}

A.O.A.C., (1980). Official Methods of Analysis of the Association of Official Agricultural Chemists (A.O.A.C.) 12th Ed. Washington. D.C.

Abd El-Azim, W.M., R. Khater and M. Badawy (2017). Effect of biofertilization and different liquorice extracts on growth and productivity of Foeniculum vulgare, Mill. plant. Middle East Journal of Agriculture Research, 6. 1-12.

Ali, E. and F. Hassan (2014). Bioproduction of Nigella sativa L. seeds and oil in Taif area. Int.J.Curr.Microbiol.App.Sci. 3(1): 315328.

Ali, E.F., F.A.S. Hassan and M. Elgimabi (2018). Improving the growth, yield and volatile oil content of Pelargonium graveolens L. Herit by foliar application with moringa leaf extract through motivating physiological and biochemical parameters. South African Journal of Botany 119, 383389.
Alireza, Y., R.S. Aboueshaghi, M.M. Dehnavi and H. Balouchi (2014). Effect of micronutrients foliar application on grain qualitative characteristics and some physiological traits of bean (Phaseolus vulgaris L.) under drought stress. Indian J. Fund. Appl. Life Sci. 4 (4), 124-131.

Amer, S.S.A. (2004). Growth, green pods yield and seeds yield of common bean (Phaseolus vulgaris L.) as affected by active dry yeast, salicylic acid and their interaction. J. Agric Sci. Mansoura univ., 29(3): 1407-1422.

Bhuvaneshwari, L.C., A.A. Farooqi, B.S. Sreeramu and K.N. Srinivasappa (2002). Influence of nitrogen, phosphorus and potassium levels on growth, fruit yield and essential oil content in anise (Pimpinella anisum, L.). J. Spices and Aromatic crops, 11 (2):112-117.

Bistgani, Z., S. Siadat, A. Bakhshandeh, A. Pirbalouti and M. Hashemi (2017). Interactive effects of drought stress and chitosan application on physiological characteristics and essential oil yield of Thymus daenensis Celak. The Crop Journal, 5, 407-415.

Bitelli, M., M. Flury, G.S. Campbell and E.J. Nichols (2001). Reduction of transpiration through foliar application of chitosan, Agric. For. Meteorol. 107, 167-175.

Black, C.A., D.D. Evans and L.E. Ensminger (1965). Methods of Soil Analysis. Agron. J. Amer. Soc. Agron. Inc. Publ., Madison, Wisconsin, U.S.A.

British Pharmacopea (1963). Determination of Volatile Oil in Drugs. Published by Pharmaceutical Press. London. W.C.I.

Calvo, P., L. Nelson and J. Kloepper (2014). Agricultural uses of plant biostimulants. Plant and Soil, 383, 341. 
Desoky, E.M., S.A. Elrys and M.M. Rady (2019). Integrative moringa and liquorice extracts application improves Capsicum annuum fruit yield and declines its contaminant contents on a heavy metalscontaminated saline soil. Ecotoxicology and Environmental Safety. 169: 50-60.

Elrys, A.S. and A.M.A. Merwad (2017). Effect of alternative spraying with silicate and liquorice root extract on yield and nutrients uptake by pea plants. Egypt. J. Agron. 39 (3): 279292.

El-Sayed, A.A., M.K. Aly and M.H. Abd ElGawad (2002). Response of coriander plants to some phosphorus, zinc and yeast treatments. In: Proceedings of the 2nd International Conference of Horticulture Science, Kafr El-Sheikh, Tanta Univ. Egypt, 434-446.

El-Tantawy, E. M. (2009). Behaviour of tomato plants as affected by spraying with chitosan and aminofort as natural stimulator substances under application of soil organic amendments. Pak. J. Biol. Sci. 12 : 1164-73.

Ezz El-Din, A., S. Hendawy (2010). Effect of dry yeast and compost tea on growth and oil content of Borago officinalis plant. Research Journal of Agriculture and Biological Sciences, 6(4): 424-430.

Farouk, S., A. A. Mosa, A. A. Taha, Heba M. Ibrahim and A. M. El-Gahmery (2011). Protective effect of humic acid and chitosan on radish (Raphanus sativus L. var. sativus) plants subjected to cadmium stress. J. Stress Physiol. Biochem. 7 : 99-116.

Gornik, K., M. Grzesik and B. R. Duda (2008). The effect of chitosan on rooting of grape vine cuttings and on subsequent plant growth under drought and temperature stress. J. Fruit Ornam. Plant Res. 16 : 333-43.
Guan, Y., H. Jin, W. Xian-ju and S. Chenxia (2009). Seed priming with chitosan improves maize germination and seedling growth in relation to physiological changes under low temperature stress. J. Zhejiang Univ. Sci. B. 10 : 427-33.

Hadwiger, L.A. (2013). Plant science review: Multiple effects of chitosan on plant systems: Solid science or hype. Plant Sci., 208: 42-49.

Hassan, F.A.S. and E.F. Ali (2013). A comparative study between traditional mineral nutrition and other alternative sources on anise plant. Europe. J. Sci. Res. 106 (2):201-212.

Hassan, H. and M. Abd El-Samee (2015). Growth, yield and nutritional value of Hibiscus sabdariffa $L$. as influenced by liquorice and moringa aqueous extracts under North Sinai conditions. Zagazig J. Agric. Res., 42 (5), 10691079.

Heikal, A.E. 2005. Effect of organic and biofertilization on growth production and composition of (Thymus vulgaris L.) plants. M.Sc. Thesis, Fac. Agric. Cairo Univ.

Herbert, D., P.J. Phipps and R.E. Strange (1971). Determination of total carbohydrates. Methods in Microbiology, 5(8): 290-344.

Jackson, M.L. (1978). Soil Chemical Analysis. Fall Indian Private. Ltd. New Delhi.

Karimi, S., H. Abbaspour, J. M. Sinaki and H. Makarian (2012). Effects of water deficit and chitosan spraying on osmotic adjustment and soluble protein of cultivars castor bean (Ricinus communis L.). J. Physiol. Biochem. 8 : 160-69.

Kassem, A. (2013). Effect of dry yeast and whey applications on herb growth and essential oil yield of rosemary. J. Product. \& Dev., 18(3):421 - 436. 
Khedr, Z.M. and S. Farid (2000). Response of naturally virus infected plants to yeast extract and phosphoric acid application. Ann. Sci. Moshtohor, Egypt, 38: 927-939.

Kurtzman, C.P. and J.W. Fell (2005). Biodiversity and Ecophysiology of Yeasts (In: The Yeast Handbook, Gabor P, de la Rosa CL, eds) Berlin, Springer, 11-30.

Lei, C.Y., D.M. Ma, G.B. Pu, X.F. Qiu, Z.G. Du, H. Wang, G.F. Li, H.C. Ye and B.Y. Liu (2011). Foliar application of chitosan activates artemisinin biosynthesis in (Artemisia annua L.), Ind. Crop. Prod. 33: 176-182.

Malekpoor, F., A. Pirbalouti and A. Salimi (2016). Effect of foliar application of chitosan on morphological and physiological characteristics of basil under reduced irrigation. Res. on Crops 17 (2): 354-359.

Metzner, H., H. Rau and H. Senger (1965). Unter suchungen zur synchronisier barteit einzelner pigmentan angel mutanten von chlorela. Planta, 65, 186.

Moses, T.N., W.A. Abdul-Jabbar and A.N. Elwy (2002). A study of some local liquorice root powder components (Glycyrrihiza glabra L.). Iraqi J. of Agric. Sci., 33(4): 30-38.

Nasser, N.S., M.W. Mahdi and S.S. Abdullah (2014). The effect of spraying with liquorice and organic fertilization of poultry in the growth of fenugreek plant (Trigonella foenum-graecum, L.). The Swedish J. Scientific Res., 1(6): 36-42.

Piper, C.S. (1967). Soil and Plant Analysis. 2nd Ed., Asia Pub. House, Bombay, India.

Ross, I.A. (2001). Medicinal Plants of the World: Chemical Constitutes, Traditional and Modern Medicinal Uses, Humana press, Totowa, New Jersey, 2: 363-374.
Sharaf-Eldin, M., A. Ibrahim and H. Korkar (2008). Effect of gibberellic acid and dry yeast on growth, yield, and essential oil of lemon balm (Melissa officinalis L.). Medicinal and Aromatic Plant Science and Biotechnology, 2 (2): 105-109.

Snedecor, G.W. and W.G. Cochran (1980). Statistical Methods $7^{\text {th }}$ Ed., lowa State Univ., Press., Ames. lowa, U.S.

Tepe, B., A.H. Akpulat, M. Sokmen, D. Daferera, O. Yumrutas, E. Aydin, M. Polissiou and M. Sokmen (2006). Screening of the antioxidtaive and antimicrobial properties of the essential oil of Pimpinella anisum and Pimpinella flabellifolia from Turkey. Food Chemistry. 97: 719-724.

Thanaa, Sh. M., E.K. Nabila, M.S. Abou Rayya and R.A. Eisa (2016). Response of nonpareil seedlings almond to foliar application of Liquorice root extract and bread yeast suspend under south Sinai conditions. J. of Innovations in Pharmaceuticals and Biological Sci., 3(1): 123-132.

Thomas, H. and C.J. Howarth (2000). Five ways to stay green. J. Exp. Bot. 51: 329-337.

Yin, H., X.C. Fretté, L.P. Chrestensen and K. Grevsen (2011). Chitosan oligosaccharides promote the content of polyphenols in Greek oregano (Oreganum vulgare ssp. hirtum), J. Agric. Food Chem. 60: 136-143.

Zadeh, J.B., Z.M. Kor and M.K. Goftar (2013). Licoric (Glycyrrihiza glabra L.) as a valuable medicinal plant. Inter. J. of Advanced Biological and Biomedical Research, 1(10): 12811288.

Zhao, J., L.C. Davis and R. Verpoorte (2005). Elicitor signal transduction leading to production of plant secondary metabolites, Biotechnol. Adv. 23: 283-333. 
تأثير بعض المنشطات الحيوية علي النمو والمحصول ومحتوي الزيت الطيار في نبات الينسون

\section{راجيا متولي مزروع}

قسم البساتين - كلية الزراعة - جامعة المنوفية ملية

الملخص العربى أجريت هذه التجرية لاراسة تأثير المعاملة بكل من مستخلص جذور نبات العرقسوس والثشيتوسان والخميرة كمنشطات حيوية علي النمو والمحصول ومحتوي الزيت الطيار في نبات الينسون. وقد تم رش النباتات بمستخلص جذور نبات العرقسوس بمعدل 20 جم/تتر بينما استخدم الشيتوسان بتركيز 400 مجم/لتر والخميرة بتركيز 6 جم/تتر • وتم رش نباتات الكنترول بماء الصنبور .

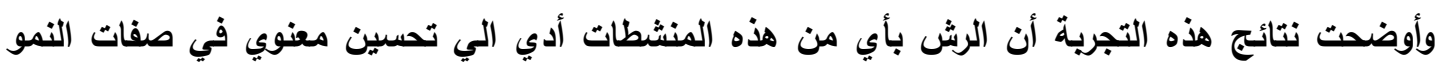

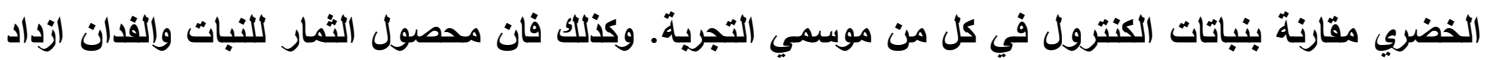
معنويا بالرش باستخدام أي من هذه المنشطات مقارنة بالنباتات الغير معاملة. ومن الجدير بالذكر أن المعاملة

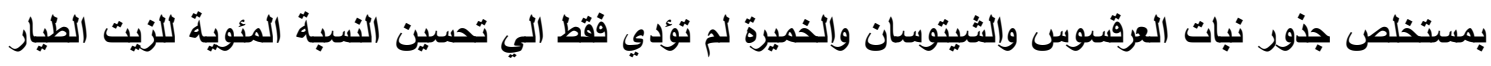
وكذلك محصول الزيت ولكنها أدت أيضا الي تحسين مكونات الزيت الطيار الرئيسية. كما أوضحت النتائج أن صبغات التمثيل الضوئي والكريوهيدرات والنسبة المئوية للنيتروجين والفوسفور والبوتاسيوم قد ازدادت بـات بمعاملة الرش بأي من هذه المنشطات الحيوية سالفة الأكر. ويصفة عامة فان أكثر هذه المنشطات الحيوية تأثيرا كان الرش بالثيتوسان ثم الرش بالخميرة في كل من موسمي التجربة. لتشيط نمو نبات الينسون وزيادة محصول

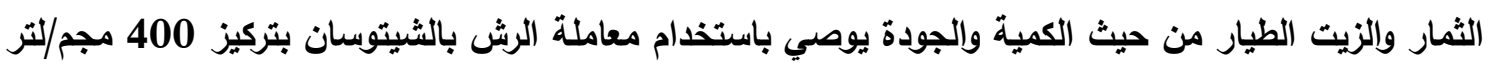

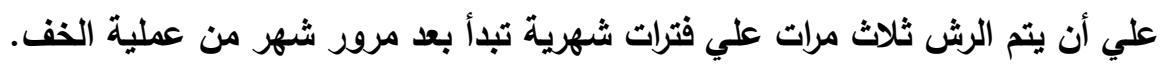


Effect of some biostimulants on growth, yield and volatile oil content ........... 